\title{
KAJIAN NILAI PELUANG DALAM PERMAINAN GICI-GICI SORONG
}

\section{Study Of Probability Values In The Gici-Gici Sorong Game}

\author{
Darma Andreas Ngilawajan * \\ Program Studi Pendidikan Matematika FKIP Universitas Pattimura \\ Jln. Ir. M. Putuhena, Kampus Unpatti, Poka-Ambon, 97233, Provinsi Maluku, Indonesia \\ e-mail: dngilawajan@fkip.unpatti.ac.id \\ Corresponding author*
}

\begin{abstract}
Abstrak
Peluang merupakan sebuah konsep dalam matematika, yang diperluas kajiannya dalam bidang statistika sebagai salah satu cabang ilmu dari matematika. Penerapan dari konsep peluang tidak hanya dalam bidang statistika, tetapi juga dapat dijumpai dalam berbagai bidang kehidupan, salah satunya dalam permainan tradisional. Gici-gici sorong adalah salah satu permainan tradisional dari Maluku yang banyak dimainkan oleh anak-anak Maluku sejak masa lampau, meski saat ini sudah sangat jarang dimainkan dan hanya ditemukan pada sebagian tempat terpencil di Maluku. Dalam permainan ini, setiap pemain berusaha mendapatkan rumah atau sarang sebanyak-banyaknya. Setiap pemain memiliki peluang yang sama untuk menang, tergantung keahliannya dalam bermain. Pemain yang memiliki sarang terbanyak yang memenangkan permainan. Metode penelitian yang digunakan dalam penulisan ini adalah studi literatur, yaitu mengkaji teori peluang dan permainan gici-gici sorong dari beberapa buku dan artikel ilmiah yang relevan, kemudian mengaitkannya dengan fokus masalah untuk mengetahui nilai peluang dalam permainan gici-gici sorong. Hasil penelitian menunjukkan bahwa nilai peluang dalam permainan gici-gici sorong semakin bertambah mendekati nilai satu seiring dengan bertambahnya jumlah sarang yang terisi.
\end{abstract}

Kata Kunci: Gici-gici Sorong, Peluang

\begin{abstract}
Probability is a concept in mathematics which extended its content in the field of statistics as a branch of mathematics. The application of probability can be found not only in statistics but also in many fields, one of those is in traditional games, even though it doesn't realized by those who played the game. Gici-gici sorong is one of traditional games in Moluccas which played by children and teenagers since uncertain time in the past until now, despite in these recent days not many children play this game and it only can be found in some remote areas around Moluccas. In this game, every player tries to make many nests as many as possible. The player who makes more nest compare to other is the winner of the game. The method which use in this paper is literature study, that is to study probability theory and the gici-gici sorong game from some books and scientific articles that relevance to the problem, in order to find out the values of probability in the gici-gici sorong game. The results show that the values of probability in the gici-gici sorong game are approaching to 1 following the increasing of filling nests.
\end{abstract}

Keywords: Probability, The Gici-Gici Sorong 


\section{PENDAHULUAN}

Istilah peluang dapat dijumpai dalam keseharian, terutama dalam aktivitas manusia terkait prediksi akan suatu kejadian. Arti dari kata peluang secara harafiah adalah kesempatan. Debnath dan Basu [7] menyatakan bahwa istilah peluang atau probabilitas diambil dari bahasa latin "probo" yang artinya mungkin. Sedangkan konsep peluang mulai dikenal sejak masa Yunani kuno, yaitu ketika Plato (428-348 SM) bersama muridnya yang terkenal yaitu Aristoteles (384-322 SM) seringkali membahas istilah "kemungkinan" dari sebuah kesempatan dan merumuskannya dalam filsafat.

Banyak definisi tentang peluang yang diberikan para ahli yang intinya menekankan kemungkinan akan terjadinya suatu hal. Salah satunya, menurut Campbell dan Shantikumar [8] bahwa sebuah peluang adalah kemungkinan akan terjadi suatu kejadian tertentu. Secara matematis, konsep peluang dirumuskan oleh dua orang matematikawan Perancis, yaitu Blaise Pascal dan Pierre de Fermat. Selanjutnya menurut Athreya [2], teori peluang menyediakan dasar matematika untuk mengkaji suatu fenomena yang bersifat acak, yaitu fenomena yang hasilnya tidak bisa diprediksi sebelumnya.

Lahirnya teori peluang, menurut Tanton [5], dimulai dari persoalan dalam permainan judi "games of chance" yang dikemukakan oleh Chevalier De Mere kepada seorang matematikawan Perancis bernama Blaise Pascal (1623-1662). De Mere, seorang bangsawan Perancis yang gemar bermain judi, mengemukakan persoalan bagaimana menentukan pemenang dari sebuah permainan taruhan yang sudah direncanakan berlangsung selama sembilan seri namun permainan terhenti pada seri ke-4 karena suatu faktor. Pada saat permainan terhenti, salah satu pemain sudah memenangkan tiga seri permainan, sedangkan pemain yang lain baru memenangkan satu seri. Blaise Pascal kemudian mendiskusikan persoalan tersebut kepada rekannya, Pierre de Fermat (1601-1665), yang juga seorang matematikawan.

Menurut Debnath dan Basu [7], dari diskusi antara Pascal dan Fermat, kemudian dibuat metode tentang cara mengatur objek-objek dan merumuskan kesempatan memenangkan permainan secara adil. Pengembangan selanjutnya, mereka memperkenalkan konsep peluang, nilai rataan (atau nilai yang diharapkan) dan peluang bersyarat. Kolaborasi antara Pascal dan Fermat tidak hanya memecahkan persoalan yang diajukan De Mere, namun mereka juga mengkonsepkan persoalan tersebut secara matematis yang dikenal sebagai teori peluang (probability theory).

Menurut Hajek [1], seiring perkembangan zaman maka konsep peluang memegang peranan pada hampir semua disiplin ilmu. Tidak hanya dalam bidang sains, konsep peluang utamanya digunakan untuk menopang penelitian di bidang sosial. Dalam dunia ekonomi dan bisnis, konsep peluang digunakan untuk memprediksi keuntungan dan kerugian dalam suatu kebijakan ekonomi. Selain dalam bidang ilmiah, penerapan konsep peluang dapat dijumpai pula dalam permainan tradisional gici-gici sorong yang merupakan permainan tradisional dari Maluku. Permainan gici-gici sorong adalah warisan dari generasi masa lampau yang umumnya dimainkan oleh anak-anak dan remaja. Dalam permainan ini, setiap pemain berusaha untuk memiliki sarang (atau sering dipakai istilah rumah) sebanyak-banyaknya sehingga bisa memenangkan permainan. Setiap usaha atau percobaan yang dilakukan masing-masing pemain tentunya berbanding dengan jumlah sarang yang tersedia. Dengan demikian, setiap pemain dapat menghitung kemungkinan jumlah sarang yang bisa dimiliki pada saat permainan berlangsung. Jika ditelusuri, proses setiap pemain menghitung jumlah sarang yang tersedia kemudian dibandingkan dengan setiap percobaan yang dilakukan sehingga bisa diprediksi kemungkinan hasil yang bisa dicapai, maka secara tak sadar mereka telah menerapkan konsep peluang secara matematis dalam permainan gici-gici sorong, meski sangat mungkin diantara mereka ada yang sama sekali tidak mengetahui konsep peluang. Hal ini menarik untuk dikaji secara mendalam, sehingga bisa dideskripsikan nilai peluang dalam permainan gici-gici sorong.

Konsep peluang dalam tulisan ini tidak diulas secara mendalam tetapi hanya dibatasi pada definisidefinisi tentang ruang sampel, kejadian, peluang suatu kejadian, dan peluang gabungan dua kejadian. Selanjutnya, definisi-definisi tersebut dikaitkan dengan permainan gici-gici sorong untuk mendeskripsikan nilai peluang dalam permainan gici-gici sorong, yaitu nilai peluang sejak awal permainan hingga tersisa satu sarang yang kosong.

Suradi [11] menyatakan bahwa gici-gici dalam bahasa Ambon berarti melompat dengan kaki satu. Merujuk pada arti kata gici-gici, maka permainan gici-gici berarti permainan yang hanya menggunakan satu kaki untuk melompat mengikuti pola tertentu. Permainan gici-gici merupakan permainan rakyat yang berasal dari pulau Buru. Permainan ini kebanyakan dimainkan di beberapa desa di Kabupaten Buru Selatan, 
antara lain di desa Mepa, desa Tifu, desa Ewiri, dan desa Waeturen. Jika melihat cara bermain, maka permainan gici-gici ditemui di hampir semua daerah di Indonesia, hanya saja berbeda pada sebutan nama permainannya dan bagan arena permainan. Febriyanti, dkk [4] menjelaskan bahwa permainan sejenis gicigici di daerah Sunda (Jawa Barat) dikenal dengan nama Tapak Gunung. Sedangkan untuk daerah lain di pulau Jawa, permainan ini dikenal dengan nama Engklek dan umumnya dimainkan oleh anak perempuan.

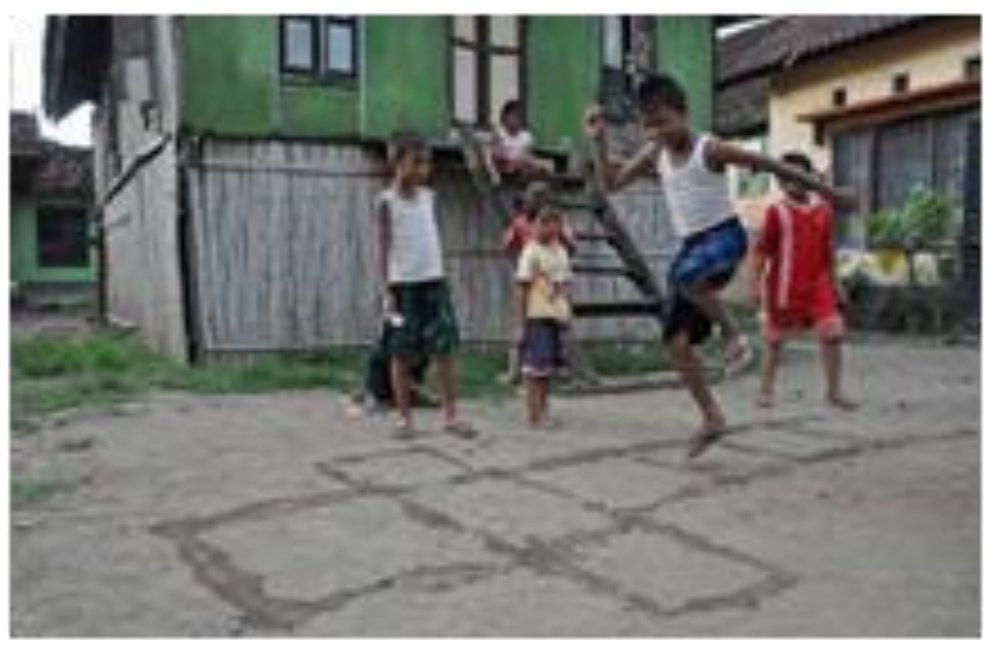

Gambar 1. Ilustrasi Permainan Gici-Gici Sumber: Uniqpost.com

Menurut Suradi [11] alat yang dibutuhkan dalam permainan gici-gici hanya batu pipih kecil yang diberi nama gacu dan arena bermain yang bisa digambar di tanah atau pada jenis lantai yang keras dengan menggunakan kapur. Lebih lanjut, Suradi menyatakan bahwa dikenal beberapa jenis permainan gici-gici di Maluku yang namanya mengikuti bentuk arena permainan dan cara bermain, salah satu diantaranya adalah gici-gici sorong. Dinamakan gici-gici sorong karena dalam permainan ini setiap pemain menggeser (sorong) gacu melewati semua kotak pada arena permainan tanpa menyentuh batasan garis atau keluar dari arena permainan.

Untuk cara bermain, setiap pemain memulai permainan dengan menggeser gacu melewati semua kotak dengan hanya menggunakan 1 kaki. Jika berhasil melewati semua kotak tanpa menyentuh garis atau keluar arena permainan pada saat gacu terhenti, kemudian gacu dilempar melewati kepala dengan posisi membelakang arena untuk mencari sarang dan jika gacu yang jatuh menyentuh tanah dalam kotak, maka kotak atau sarang tersebut dapat ditempati pemain yang berhasil dan diberi tanda tertentu. Jika proses permainan tidak lancar, dalam arti saat gacu digeser kemudian terhenti menyentuh batas garis antar kotak, keluar arena permainan, atau gacu yang dilempar tidak menempati dalam kotak, maka giliran main diberikan kepada pemain berikutnya. Permainan terhenti jika semua sarang telah terisi.

Permainan gici-gici sorong umumnya dimainkan oleh anak-anak hingga remaja perempuan. Meski demikian, tidak menutup kemungkinan dimainkan juga oleh anak-anak laki-laki. Permainan ini biasanya dimainkan oleh 2 sampai 5 orang dan sifatnya hanya sebagai hiburan atau permainan rakyat. Bagan arena permainan gici-gici sorong ditunjukkan dalam Gambar 2, berikut:

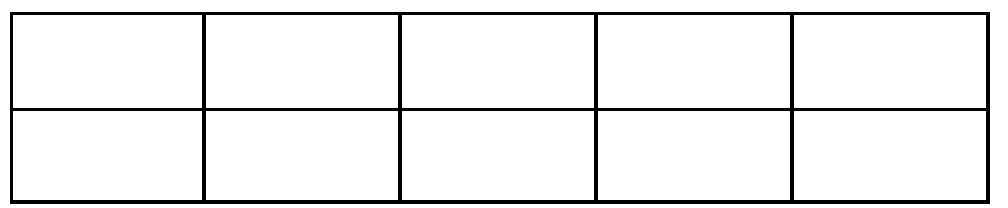

Gambar 2. Bentuk Arena Permainan Gici-gici Sorong (Tampilan Horizontal) 


\section{METODE PENELITIAN}

Penelitian ini termasuk jenis penelitian studi literatur. Menurut Sugiyono [11], studi literatur berkaitan dengan kajian teoritis dan referensi lain yang terkait dengan nilai, budaya dan norma yang berkembang pada situasi yang diteliti. Dalam penelitian ini, dikaji teori peluang, permainan gici-gici dan gici-gici sorong dari 10 sumber literatur berupa buku dan artikel ilmiah yang relevan dengan masalah yang diteliti. Secara rinci, untuk teori peluang menggunakan 3 buku dan 5 artikel ilmiah. Sedangkan untuk permainan gici-gici sorong menggunakan 1 buku, dan permainan gici-gici menggunakan 1 buku dan 1 artikel ilmiah. Keterangan menyangkut sumber secara jelas dapat dilihat pada bagian daftar pustaka.

\section{HASIL DAN PEMBAHASAN}

\subsection{Uraian Teori}

Berikut ini diberikan beberapa definisi, yaitu definisi ruang sampel yang bersumber pada [9] dan [10], definisi kejadian dan peluang suatu kejadian yang bersumber pada [3], [9] dan [10], dan peluang gabungan dua kejadian yang bersumber pada [3], [8], dan [10].

Definisi 1. Himpunan semua hasil yang mungkin dari suatu percobaan Statistika disebut ruang sampel dan dilambangkan dengan $\tau$.

Tiap hasil dari ruang sampel disebut unsur atau anggota ruang sampel atau titik sampel. Bila ruang sampel mempunyai unsur yang hingga banyaknya, maka anggotanya dapat didaftar dengan menuliskannya di dalam kurung kurawal dan masing-masing unsur dipisah oleh tanda koma.

Sebagai contoh, sekeping uang logam yang mempunyai sisi muka (M) dan belakang (B) dilantunkan sekali, maka kumpulan semua hasil yang mungkin atau ruang sampelnya dapat ditulis sebagai $\tau=\{M, B\}$, dengan $\mathrm{M}$ dan B adalah titik-titik sampel.

Contoh yang lain, sebuah dadu dilantunkan sekali dan yang diselidiki adalah angka yang muncul di sebelah atas, maka ruang sampelnya adalah $\tau=\{1,2,3,4,5,6\}$, dengan titik-titik sampelnya adalah angka 1 hingga 6.

Definisi 2. Suatu kejadian adalah himpunan bagian dari ruang sampel.

Munculnya sebuah mata dadu yang diharapkan dalam percobaan lantunan sebuah dadu disebut sebagai kejadian dan diberi notasi huruf besar. Misalnya, kejadian A adalah munculnya mata dadu 5. Jika dihubungkan dengan ruang sampel, maka suatu kejadian merupakan himpunan bagian dari ruang sampel. Sehingga, kejadian A yang merupakan kejadian munculnya mata dadu 5 dapat ditulis dalam notasi himpunan sebagai $A=\{5\}$, dimana $A \subset \tau$, dengan $\tau=\{1,2,3,4,5,6\}$.

Definisi 3. Bila suatu percobaan dapat menghasilkan $\mathrm{N}$ hasil yang saling meniadakan dan berkemungkinan sama, dan bila $n(A)$ dari hasil tersebut bersifat $\mathrm{A}$, maka:

$$
P(A)=\text { peluang } A=\frac{n(A)}{N}
$$

Jika dipandang percobaan dengan ruang sampel yang jumlah unsurnya berhingga maka kemungkinan terjadinya suatu kejadian sebagai hasil percobaan statistika dinilai dengan menggunakan sekumpulan bilangan real disebut bobot atau peluang dari 0 sampai 1 . Jika diyakini bahwa suatu titik sampel tertentu kemungkinan besar akan terjadi, maka seharusnya bobotnya dekat dengan 1. Sebaliknya, bobot yang hampir nol diberikan kepada titik sampel yang kecil sekali kemungkinannya terjadi. Untuk titik di luar sampel (yang menggambarkan kejadian sederhana yang tidak mungkin terjadi) diberi bobot 0 .

Untuk menentukan peluang suatu kejadian A, semua bobot titik sampel dalam A dijumlahkan. Jumlah ini dinamakan peluang A dan dinyatakan dengan $\mathrm{P}(\mathrm{A})$. Secara singkat dapat dibuat definisi berikut:

Definisi 4. Peluang suatu kejadian $A$ adalah jumlah bobot semua titik sampel yang termasuk $A$, sehingga:

$$
0 \leq P(A) \leq 1, P(\varnothing)=0, P(\tau)=1
$$


Dengan $0 \leq P(A) \leq 1$ merupakan interval nilai peluang, $P(\varnothing)=0$ merupakan peluang suatu kejadian yang bukan himpunan bagian dari ruang sampel, dan $P(\tau)=1$ adalah peluang dari kejadian munculnya himpunan yang merupakan ruang sampel.

Definisi 5. Peluang gabungan (union) dua kejadian dinyatakan sebagai:

$$
P(A \cup B)=P(A)+P(B)-P(A \cap B)
$$

Jika kedua kejadian saling lepas, maka $P(A \cap B)=0$, sehingga definisi 5 dapat dikembangkan menjadi definisi 6.

Definisi 6. Peluang dua kedua kejadian saling lepas dinyatakan sebagai:

$$
P(A \cup B)=P(A)+P(B)
$$

Dari definisi 6, jika diasumsikan $P(A)=P(\emptyset)=0$ atau $P(B)=P(\varnothing)=0$, maka dapat dibuat definisi berikut:

Definisi 7. Peluang dua kejadian saling lepas, jika salah satu kejadian merupakan kejadian yang mustahil terjadi atau peluang kejadiannya bernilai 0 , adalah:

$$
P(A \cup \emptyset)=P(A)+P(\varnothing)=P(A) \text { atau } P(\varnothing \cup B)=P(\varnothing)+P(B)=P(B)
$$

Setelah uraian definisi-definisi yang telah dipaparkan, selanjutnya dibahas perhitungan nilai peluang dalam permainan gici-gici sorong dengan menggunakan definisi-definisi tersebut. Perhitungan nilai peluang dilakukan secara terurut, yaitu sejak dimulainya permainan hingga tersisa satu sarang kosong.

\subsection{Menghitung Nilai Peluang Dalam Permainan Gici-Gici Sorong}

Sebelum dilakukan perhitungan nilai peluang, terlebih dulu dibuat rekonstruksi dari gambar arena permainan gici-gici sorong dengan memberi label huruf dan angka untuk masing-masing sarang sehingga memudahkan dalam membuat ruang sampel dan menghitung nilai peluang. Gambar 3, rekonstruksi dari arena permainan gici-gici sorong ditunjukkan sebagai berikut:

\begin{tabular}{|c|c|c|c|c|}
\hline $\mathrm{A} 1$ & $\mathrm{~A} 2$ & $\mathrm{~A} 3$ & $\mathrm{~A} 4$ & $\mathrm{~A} 5$ \\
\hline $\mathrm{B} 1$ & $\mathrm{~B} 2$ & $\mathrm{~B} 3$ & $\mathrm{~B} 4$ & $\mathrm{~B} 5$ \\
\hline
\end{tabular}

\section{Gambar 3. Rekonstruksi gambar arena permainan Gici-gici Sorong yang dibuat horizontal}

Dari Gambar 3, dapat dibuat ruang sampel yang memuat label-label dalam kotak, sehingga ruang sampel yang terbentuk adalah $\tau=\{A 1, A 2, A 3, A 4, A 5, B 1, B 2, B 3, B 4, B 5\}$. Ruang sampel ini jika dikaitkan dengan definisi 1 maka mengandung pengertian himpunan sarang yang mungkin ditempati setiap pemain dalam permainan. Label-label A1, A2, A3, A4, A5, B1, B2, B3, B4, B5 merupakan titik-titik sampel, dan jika dikaitkan dengan definisi 2, dapat diartikan sebagai kejadian seorang pemain menempati sarang A1, atau A2, dan seterusnya hingga B5.

Selanjutnya diasumsikan bahwa permainan ini dimainkan oleh 3 orang (catatan: jika dimainkan oleh jumlah pemain yang berbeda pun, maka peluang yang dimiliki setiap pemain tetap sama. Perhitungan nilai peluang dilakukan ketika setiap pemain telah berada pada tahap melempar gacu melewati kepala dengan posisi tubuh membelakangi arena permainan. Setiap pemain mempunyai peluang menempati 1 sarang setiap 1 kali percobaan melempar gacu. Jika gacu yang dilempar jatuh dalam kotak maka nilai peluang dihitung dengan membandingkan jumlah sarang yang ditempati dengan jumlah ruang sampel yang tersedia. 
Jika gacu yang dilempar jatuh pada garis batas kotak atau di luar arena permainan, maka tidak ada sarang yang ditempati yang dianalogikan sebagai kejadian yang berada di luar ruang sampel, sehingga peluangnya adalah $P(\emptyset)=0$.

Pada setiap kondisi jumlah sarang yang terisi, akan dinamakan "kejadian" dan diikuti huruf kapital. Pada kondisi awal permainan, yaitu saat belum ada sarang yang terisi, akan dinamakan "kejadian $A$ ". Pada saat 1 sarang telah terisi akan dinamakan "kejadian B", dan seterusnya.

Sebagai tambahan, pemberian warna atau tanda yang berbeda pada setiap kotak dalam gambar untuk setiap kejadian merupakan ilustrasi dari penempatan sarang oleh pemain yang berbeda. Setiap sarang hanya bisa diisi 1 pemain, dengan kata lain 2 pemain yang berbeda tidak dapat menempati sarang yang sama. Perhitungan nilai peluang untuk masing-masing kejadian dijabarkan sebagai berikut:

\section{a. Kejadian A: Belum ada sarang yang terisi}

Dengan menggunakan gambar 3, ruang sampel yang terbentuk pada awal permainan adalah $\tau=$ $\{A 1, A 2, A 3, A 4, A 5, B 1, B 2, B 3, B 4, B 5\}$. Banyaknya elemen ruang sampel $=n(\tau)=10$. Banyaknya hasil yang diharapkan muncul = banyaknya sarang kosong yang mungkin ditempati $=n(A)=1$ (artinya sarang yang mungkin ditempati adalah A1, atau A2, atau A3, ..., atau B5). Saat melempar gacu, setiap pemain mempunyai peluang menempatkan gacu pada salah satu kotak, atau mungkin juga lemparannya bisa keluar dari arena permainan, atau posisi jatuhnya gacu pada garis batas kotak. Kejadian gacu yang jatuh di luar arena permainan atau mengenai garis batas kotak merupakan kejadian di luar ruang sampel (diberi simbol $\varnothing$ ) yang nilai peluangnya dinyatakan sebagai $P(\emptyset)=0$. Peluang yang dimiliki setiap pemain pada kejadian A dapat dihitung dengan menggunakan definisi 7 , sebagai berikut:

$$
\begin{aligned}
P(A \cup \emptyset) & =P(A)+P(\varnothing) \\
& =\frac{1}{10}+0 \\
& =0,1
\end{aligned}
$$

Mengacu pada perhitungan nilai peluang kejadian A, maka kejadian $\emptyset$ yang peluangnya $P(\varnothing)=0$ dapat dikesampingkan dalam perhitungan nilai peluang untuk kejadian-kejadian berikutnya, sehingga perhitungannya menjadi lebih sederhana.

\section{b. Kejadian B: 1 Sarang telah terisi} berikut:

Misalkan B3 adalah sebarang sarang yang ditempati seorang pemain. Ilustrasi gambar dibuat sebagai

\begin{tabular}{|c|c|c|c|c|}
\hline A1 & A2 & A3 & A4 & A5 \\
\hline B1 & B2 & B3 & B4 & B5 \\
\hline
\end{tabular}

Gambar 4. Ilustrasi kejadian B

Dari gambar 4, ruang sampel yang terbentuk pada kondisi sarang B3 telah ditempati adalah $\tau=$ $\{A 1, A 2, A 3, A 4, A 5, B 1, B 2, B 4, B 5\}$. Jika dihubungkan dengan definisi 1 , ruang sampel pada kejadian $\mathrm{B}$ mengandung arti bahwa sarang lain masih mungkin ditempati, kecuali sarang B3. Banyaknya elemen ruang sampel $=n(\tau)=9$. Banyaknya hasil yang diharapkan muncul $=$ banyaknya sarang kosong yang mungkin ditempati $=n(B)=1$ (yaitu A1, atau $\mathrm{A} 2$, atau $\mathrm{A} 3$, atau $\mathrm{A} 4$, atau $\mathrm{A} 5$, atau $\mathrm{B} 1$, atau $\mathrm{B} 2$, atau $\mathrm{B} 4$ atau $\mathrm{B} 5$ ). Dengan menggunakan definisi 3 , besar nilai peluang yang dimiliki setiap pemain pada kejadian $B$ dapat dihitung sebagai:

$$
P(B)=\frac{n(B)}{n(\tau)}=\frac{1}{9}=0,111 \text { (pembulatan hingga } 3 \text { tempat desimal) }
$$

\section{c. Kejadian C : 2 Sarang telah terisi}

Misalkan A5 adalah sebarang sarang lain yang ditempati pada kejadian C. Ilustrasinya ditunjukkan dalam Gambar 5, berikut: 


\begin{tabular}{|c|c|c|c|c|}
\hline A1 & A2 & A3 & A4 & A5 \\
\hline B1 & B2 & B3 & B4 & B5 \\
\hline
\end{tabular}

Gambar 5. Ilustrasi kejadian C

Mengacu pada gambar 5, ruang sampel pada kondisi sarang B3 dan A5 telah terisi adalah $\tau=$ $\{A 1, A 2, A 3, A 4, B 1, B 2, B 4, B 5\}$. Banyaknya elemen ruang sampel $=n(\tau)=8$. Banyaknya hasil yang diharapkan muncul $=$ banyaknya sarang kosong yang mungkin ditempati $=n(C)=1$ (yaitu A1, atau A2, atau A3,... atau B5; kecuali A5 dan B3).

Selanjutnya, peluang yang dimiliki setiap pemain pada kejadian $\mathrm{C}$ sesuai definisi 3 adalah:

$$
P(C)=\frac{n(C)}{n(\tau)}=\frac{1}{8}=0,125
$$

\section{d. Kejadian D : 3 Sarang telah terisi}

Untuk kejadian D, misalkan sebarang sarang lain ditempati selain sarang A5 dan B3 adalah sarang A2. Ilustrasi kejadian D ditunjukkan dalam Gambar 6, berikut:

\begin{tabular}{|c|c|c|c|c|}
\hline A1 & A2 & A3 & A4 & A5 \\
\hline B1 & B2 & B3 & B4 & B5 \\
\hline
\end{tabular}

Gambar 6. Ilustrasi kejadian D

Dari Gambar 6, ruang sampel untuk kejadian D adalah $\tau=\{A 1, A 3, A 4, B 1, B 2, B 4, B 5\}$. Banyaknya elemen ruang sampel $=n(\tau)=7$. Banyaknya hasil yang diharapkan muncul $=$ banyaknya sarang kosong yang mungkin ditempati $=n(D)=1$ (yaitu A1, atau A3, atau A4, atau B1, atau B2, atau B4, atau B5) .

Mengacu pada definisi 3, nilai peluang yang dimiliki setiap pemain pada kejadian D adalah:

$$
P(D)=\frac{n(D)}{n(\tau)}=\frac{1}{7}=0,142 \quad \text { (pembulatan hingga } 3 \text { tempat desimal) }
$$

\section{e. Kejadian E : 4 Sarang telah terisi}

Misalkan tambahan sarang baru yang terisi adalah B4, selain sarang A2, A5, dan B3. Ilustrasinya ditunjukkan dalam Gambar 7, berikut:

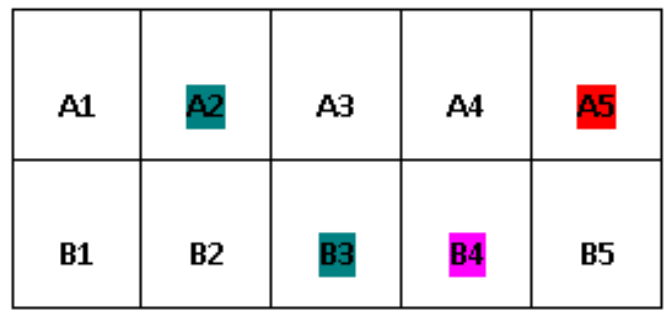

Gambar 7. Ilustrasi kejadian D

Merujuk pada Gambar 7, ruang sampel untuk kejadian E adalah $\tau=\{A 1, A 3, A 4, B 1, B 2, B 5\}$. Banyaknya elemen ruang sampel $=n(\tau)=6$. Banyaknya hasil yang diharapkan muncul $=$ banyaknya sarang kosong yang mungkin ditempati $=n(E)=1$ (yaitu $\mathrm{A} 1$, atau $\mathrm{A} 3$, atau A4, atau B1, atau B2, atau B5)

Dengan menggunakan definisi 3, peluang yang dimiliki setiap pemain untuk kejadian $\mathrm{E}$ adalah:

$$
P(E)=\frac{n(E)}{n(\tau)}=\frac{1}{6}=0,166 \quad \text { (pembulatan hingga } 3 \text { tempat desimal) }
$$




\section{f. Kejadian F: 5 Sarang telah terisi}

Misalkan sarang B1 adalah sebarang sarang baru yang terisi selain 4 sarang yang telah ditempati pada kejadian sebelumnya. Ilustrasinya ditunjukkan dalam Gambar 8, berikut:

\begin{tabular}{|c|c|c|c|c|}
\hline A1 & A2 & A3 & A4 & A5 \\
\hline B1 & B2 & B3 & B4 & B5 \\
\hline
\end{tabular}

Gambar 8. Ilustrasi kejadian F

Dari Gambar 8, ruang sampel yang terbentuk pada kejadian $\mathrm{F}$ adalah $\tau=\{A 1, A 3, A 4, B 2, B 5\}$. Banyaknya elemen ruang sampel $=n(\tau)=5$. Banyaknya hasil yang diharapkan muncul $=$ banyaknya sarang kosong yang mungkin ditempati $=n(F)=1$ (yaitu $\mathrm{A} 1$, atau $\mathrm{A} 3$, atau A4, atau B2, atau B5)

Dengan menggunakan definisi 3, nilai peluang yang dimiliki setiap pemain pada kejadian $\mathrm{F}$ adalah:

$$
P(F)=\frac{n(F)}{n(\tau)}=\frac{1}{5}=0,2
$$

\section{g. Kejadian G: 6 Sarang telah terisi}

Untuk kejadian F, misalkan bahwa sebarang sarang baru yang ditempati adalah B5. Ilustrasi dari kejadian ini ditunjukkan dalam Gambar 9, berikut:

\begin{tabular}{|c|c|c|c|c|}
\hline A1 & A2 & A3 & A4 & A5 \\
\hline B1 & B2 & B3 & B4 & B5 \\
\hline
\end{tabular}

Gambar 9. Ilustrasi kejadian G

Merujuk pada Gambar 9, ruang sampel yang terbentuk adalah $\tau=\{A 1, A 3, A 4, B 2\}$. Banyaknya elemen ruang sampel $=n(\tau)=4$. Banyaknya hasil yang diharapkan muncul $=$ banyaknya sarang kosong yang mungkin ditempati $=n(G)=1$ (yaitu A1, atau A3, atau A4, atau B2).

Maka, nilai peluang yang dimiliki setiap pemain pada kejadian $\mathrm{G}$ merujuk pada definisi 3 adalah:

$$
P(G)=\frac{n(G)}{n(\tau)}=\frac{1}{4}=0,25
$$

\section{h. Kejadian H: 7 Sarang telah terisi}

Misalkan A4 adalah sebarang sarang baru yang terisi untuk kejadian H. Ilustrasinya ditunjukkan dalam Gambar 10, berikut:

\begin{tabular}{|c|c|c|c|c|}
\hline A1 & A2 & A3 & A4 & A5 \\
\hline B1 & B2 & B3 & B4 & B5 \\
\hline
\end{tabular}

Gambar 10. Ilustrasi kejadian H

Ruang sampel yang terbentuk dari gambar 10 adalah $\tau=\{A 1, A 3, B 2\}$. Banyaknya elemen ruang sampel $=$ $n(\tau)=3$. Banyaknya hasil yang diharapkan muncul = banyaknya sarang kosong yang mungkin ditempati $=$ $n(H)=1$ (yaitu A1, atau A3, atau B2)

Merujuk pada definisi 3, nilai peluang yang dimiliki setiap pemain pada kejadian $\mathrm{H}$ adalah: 


$$
P(H)=\frac{n(H)}{n(\tau)}=\frac{1}{3}=0,333 \quad \text { (pembulatan hingga } 3 \text { tempat desimal) }
$$

\section{i. Kejadian I: 8 Sarang telah terisi}

Untuk kejadian I, misalkan tambahan sebarang sarang baru yang terisi adalah sarang A1. Ilustrasinya ditunjukkan dalam Gambar 11, berikut:

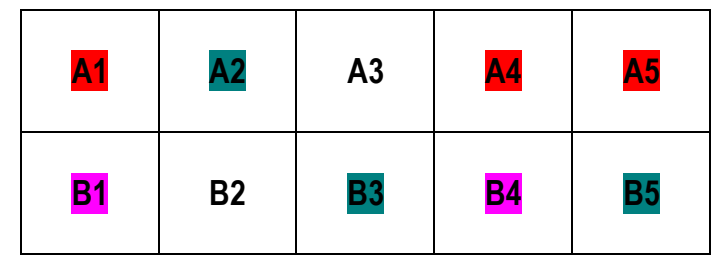

Gambar 11. Ilustrasi kejadian I

Dari Gambar 11, ruang sampel untuk kejadian I adalah $\tau=\{A 3, B 2\}$. Banyaknya elemen ruang sampel $=$ $n(\tau)=2$. Banyaknya hasil yang diharapkan muncul $=$ banyaknya sarang kosong yang mungkin ditempati $=$ $n(I)=2($ yaitu A3, atau B2)

Dengan menggunakan definisi 3, nilai peluang yang dimiliki setiap pemain pada kejadian I adalah:

$$
P(I)=\frac{n(I)}{n(\tau)}=\frac{1}{2}=0,5
$$

\section{j. Kejadian J: 9 Sarang telah terisi}

Pada kejadian J, hanya tersisa 1 sarang yang masih kosong. Misalkan bahwa tambahan sarang baru adalah A3, maka ilustrasinya dapat ditunjukkan, sebagai berikut:

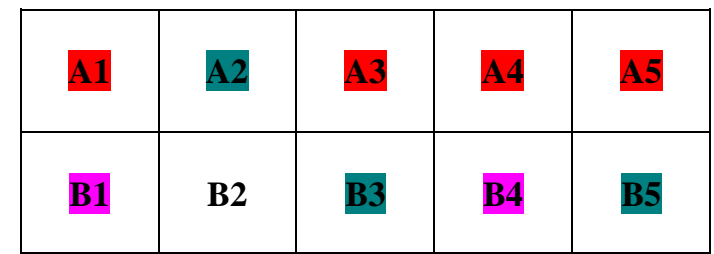

Gambar 11. Ilustrasi kejadian J

Dari gambar 12, ruang sampel pada kondisi hanya sarang B2 yang belum terisi adalah $\tau=\{B 2\}$. Banyaknya elemen ruang sampel $=n(\tau)=1$. Banyaknya hasil yang diharapkan muncul $=$ banyaknya sarang kosong yang mungkin terisi $=n(J)=1$ (yaitu B2)

Maka, nilai peluang yang dimiliki setiap pemain untuk kejadian J, merujuk pada definisi 3 adalah:

$$
P(J)=\frac{n(J)}{n(\tau)}=\frac{1}{1}=1
$$

\subsection{Deskripsi Nilai Peluang Dalam Permainan Gici-Gici Sorong}

Pada bagian ini dibuat tabulasi dari perhitungan nilai peluang untuk kejadian A hingga kejadian J, yang dilakukan dengan menggunakan definisi 3 dan definisi 7. Melalui tabulasi, deskripsi keseluruhan nilai peluang dalam permainan gici-gici sorong dapat terlihat secara singkat dan jelas, yang ditunjukkan dalam Tabel berikut:

Tabel 1. Deskripsi Nilai Peluang Dalam Permainan Gici-gici Sorong

\begin{tabular}{|c|c|c|c|}
\hline \multirow{2}{*}{ Kejadian } & \multirow{2}{*}{ Nilai Peluang } & \multicolumn{2}{|c|}{ Jumlah Sarang } \\
\cline { 3 - 4 } & & Terisi & Kosong \\
\hline A & 0,1 & 0 & 10 \\
\hline B & 0,111 & 1 & 9 \\
\hline C & 0,125 & 2 & 8 \\
\hline D & 0,142 & 3 & 7 \\
\hline
\end{tabular}




\begin{tabular}{|c|c|c|c|}
\hline $\mathrm{E}$ & 0,166 & 4 & 6 \\
\hline $\mathrm{F}$ & 0,2 & 5 & 5 \\
\hline $\mathrm{G}$ & 0,25 & 6 & 4 \\
\hline $\mathrm{H}$ & 0,333 & 7 & 3 \\
\hline $\mathrm{I}$ & 0,5 & 8 & 2 \\
\hline $\mathrm{J}$ & 1 & 9 & 1 \\
\hline
\end{tabular}

Dari Tabel 1, dibuat deskripsi nilai peluang untuk setiap kejadian, sebagai berikut:

1. Pada kejadian A, saat belum ada sarang yang terisi, nilai peluang mendekati 0 , yaitu 0,1 . Ini mengandung artinya setiap pemain memiliki peluang 0,1 secara acak untuk menempati 10 sarang yang masih kosong.

2. Pada kejadian B, saat 1 sarang telah ditempati, nilai peluang sedikit bertambah menjauhi 0 , yaitu 0,111 . Ini mengandung arti bahwa setiap pemain memiliki peluang 0,111 untuk menempati 9 sarang yang masih kosong secara acak.

3. Pada kejadian $C$, saat 2 sarang telah ditempati, nilai peluang 0,125 . Artinya, setiap pemain memiliki peluang 0,125 untuk menempati 8 sarang kosong secara acak.

4. Pada kejadian D, ketika 3 sarang telah terisi, nilai peluang adalah 0,142 . Artinya bahwa setiap pemain memiliki peluang 0,142 untuk menempati secara acak 7 sarang yang masih kosong.

5. Pada kejadian E, ketika 4 sarang telah ditempati, masing-masing pemain memiliki peluang 0,166 untuk menempati 6 sarang kosong secara acak.

6. Pada kejadian F, ketika tersisa 5 sarang kosong, masing-masing pemain mempunyai peluang 0,2 untuk menempati secara acak 5 sarang yang kosong tersebut.

7. Pada kejadian $\mathrm{G}$, ketika telah terisi 6 sarang, maka setiap pemain mempunyai peluang 0,25 untuk menempati 4 sarang kosong secara acak.

8. Pada kejadian $\mathrm{H}$, ketika telah terisi 7 sarang, maka setiap pemain mempunyai peluang 0,333 untuk menempati 3 sarang yang masih kosong secara acak.

9. Pada kejadian I, ketika masih tersisa 2 sarang yang kosong, maka masing-masing pemain mempunyai peluang 0,5 untuk menempati kedua sarang kosong tersebut secara acak.

10. Pada kejadian J, ketika hanya tersisa 1 sarang yang belum terisi, maka sudah pasti setiap pemain mempunyai peluang 1 untuk menempati 1 sarang yang kosong tersebut.

11. Dari tabel, dapat dilihat perambatan nilai peluang untuk seluruh kejadian adalah: $0.1,0.111,0.125$, $0.142,0.166,0.2,0.25,0.333,0.5,1$. Perambatan nilai peluang mendekati 0 pada saat semua sarang belum terisi dan bergerak menjauhi 0 seiring bertambahnya jumlah sarang yang terisi, dan mencapai 1 ketika hanya tersisa 1 sarang yang kosong.

12. Jika melihat perambatan nilai peluang dalam permainan gici-gici sorong untuk seluruh kejadian, terlihat bahwa nilai peluang berkisar antara 0 hingga 1, yang memenuhi definisi 4 tentang interval nilai peluang, yaitu $0 \leq P(A) \leq 1$.

\section{KESIMPULAN}

Berdasarkan pembahasan, dapat disimpulkan bahwa nilai peluang dalam permainan gici-gici sorong mendekati 0 saat semua sarang masih kosong, bergerak menjauhi 0 seiring bertambahnya jumlah sarang yang terisi, dan nilai peluang sama dengan 1 saat hanya tersisa 1 sarang yang kosong.

\section{DAFTAR PUSTAKA}

[1] A. Hajek, "Interpretations of Probability", Stanford Encyclopedia of Philosophy, Versi online dapat diakses di link: https://plato.stanford.edu/entries/probability-interpret/ [diakses 7 Maret 2019]

[2] K. B. Athreya, "What is Probability Theory?", Resonance-Journal of Science Education, Vol. 20, Issue 4 (Page 292-310), April, 2015.

[3] E. J. Dudewicz, \& S. N. Mishra, "Statistika Matematika Modern", Penerbit: Penerbit ITB, Bandung, 1995.

[4] C, Febriyanti, dkk. "Etnomatematika Pada Permainan Tradisional Engklek dan Gasing Khas Kebudayaan Sunda", Barekeng: Jurnal Ilmu Matematika dan Terapan, Vol. 12 No. 1, pp. 01-06, 2018.

[5] H. Suradi, "Permainan Rakyat Daerah Maluku", Penerbit: Departemen Pendidikan Dan Kebudayaan-Proyek Inventarisasi Dan Dokumentasi Kebudayaan Daerah, Jakarta, 1981. 
[6] J. Tanton, "Encyclopedia of Mathematics", Penerbit: Facts on File Inc, New York, 2005.

[7] L. Debnath, \& K. Basu, "A Short History of Probability Theory And its Applications", International Journal of Mathematics Education, Vol 46, page 1-22, 2010.

[8] M. J. Campbell, \& S. Shantikumar, "Elementary Probability Theory", Versi online diakses pada link: https://www.healthknowledge.org.uk/public-health-textbook/research-methods/lb-statistical-methods/elementaryprobability-theory [diakses 7 Maret 2019].

[9] P. Radke, "Basic Probability Theory and Statistics", Versi online diakses pada link: https://towarsdatascience.com/basic-probability-theory-and-statistics-3105ab637213 [diakses 10 Maret 2019 ].

[10] R. E. Walpole, \& R. H. Myers, "Ilmu Peluang dan Statistika Untuk Insinyur dan Ilmuwan", Edisi ke-4. Penerbit. Penerbit ITB. Bandung. 1995.

[11] Sugiyono, "Metode Penelitian Pendidikan (Pendekatan Kuantitatif, Kualitatif, dan R\&D)", Penerbit: CV. Alfabet, Bandung, 2012. 
